\title{
Wet forensische zorg: doelen, middelen en verwachte knelpunten
}

\author{
Prof. mr. P.A.M. Mevis, mr. A.W.T. Klappe E prof. mr. M.J.F. van der Wolf
}

\section{Inleiding}

De Wet forensische zorg (Wfz) ${ }^{1}$ is op 1 januari 2019 reeds grotendeels in werking getreden. De strafrechtelijk niet onbelangrijke rest volgt - als alles goed gaat - op 1 januari 2020. In deze bijdrage wordt een overzicht gegeven van de doelen en inhoud van de wet, waarbij we ons vanwege het anticiperende karakter van dit nummer vooral richten op de nog in werking te treden onderdelen. Het ingrijpende karakter van deze onderdelen verklaart niet alleen waarom ze zijn uitgesteld, maar ook waarom wij daar het meeste aandacht op vestigen. Dat betreft in de eerste plaats de mogelijkheid voor de strafrechter om een zorgmachtiging af te geven in de zin van de Wet verplichte geestelijke gezondheidszorg (Wvggz) in artikel 2.3 Wfz. In de tweede plaats de mogelijkheid van doorbreking van het medisch beroepsgeheim bij bepaalde verdachten die (deels) weigeren mee te werken aan gedragskundig onderzoek. Deze laatste wijziging was geen onderdeel van het oorspronkelijke wetsvoorstel en dient ook een ander doel.

In deze bijdrage zullen we naast de beschrijving van deze regelingen ook een inschatting trachten te maken van de mate waarin ze tegemoet (zullen) komen aan de beoogde doelen en welke knelpunten daarbij te verwachten zijn. Bij die inschatting is het overigens niet onproblematisch dat de wet onderdeel is van een niet altijd even doorzichtig groter geheel van bestaande en aankomende regeling van gedwongen en 'gedrongen' (niet alleen forensische) zorg. ${ }^{2}$ Een tweede belemmering voor die inschatting is dat de uitvoeringsregelingen van het Besluit forensische zorg en de Regeling forensische zorg pas in juni en juli van dit jaar vastlagen, ${ }^{3}$ terwijl het Besluit Adviescommissie gegevensverstrekking weigerende observandi slechts nog in conceptversie beschikbaar is. Gezien de complexiteit van de wetten, was het verstandiger geweest de wetten niet aan te nemen voordat ook de uitvoeringsregelingen gemaakt zouden zijn. Uiteindelijk zal uiteraard de uitvoering na inwerkingtreding - niet ongewoon en niet onbegrijpelijk bij dergelijke ingewikkelde wetge-

* Paul Mevis is hoogleraar straf- en strafprocesrecht aan de Erasmus Universiteit Rotterdam. Astrid Klappe is stafjurist strafrecht bij het Landelijk Bureau Vakinhoud rechtspraak. Michiel van der Wolf is hoogleraar forensische psychiatrie aan de Universiteit Leiden.

1 Wet van 24 januari 2018; Stb. 2018, 38. Zie voor de inwerkingtreding van de verschillende onderdelen van de Wfz het Besluit van 11 december 2018; Stb. 2018, 498.

2 Zie daarover eerder in dit blad: P.A.M. Mevis \& M.J.F. van der Wolf, 'Gedwongen zorg voor volwassenen', TvGR 2015, p. 212-220.

3 Besluit forensische zorg (Bfz), Stb. 2019, 230 (incl. nota van toelichting); Regeling forensische zorg (Rfz), Stcrt. 2019, 38718 . 
vingsoperaties - nog voldoende aan reparatiewetgeving opleveren voordat duidelijk is hoe alles echt functioneert.

\section{Een overzicht van de wet}

Organisatie en definitie van forensische zorg

De grondgedachte van de Wfz is sympathiek en zelfs voor de hand liggend: (her)organiseer de zorg in strafrechtelijk kader, de toeleiding daarheen en de doorstroom daarbinnen en naar de ggz, zodat elke verdachte of veroordeelde met de nodige voortvarendheid precies op die plaats terechtkomt waar dat uit een oogpunt van behandeling en beveiliging het meest aangewezen is. Een dynamische, 'persoonsgerichte benadering' dus, met voldoende mogelijkheden van adequate in-, door- en uitstroming, ${ }^{4}$ welke benadering men vanuit een aspect van behandeling ook mag verwachten. ${ }^{5}$

Het is te begrijpen dat de Wfz als zelfstandige wet daartoe in de eerste plaats de organisatie van de forensische zorg regelt; de Wfz is in zoverre eerst en vooral een organisatiewet. Dat karakter vindt uitdrukking in het feit dat de Wfz in de eerste drie hoofdstukken definieert wat forensische zorg is, aan wie die kan worden verleend, welke instellingen die zorg volgens de Wfz kunnen verlenen en hoe het toezicht van de minister eruitziet. Het belangrijkste middel om de beoogde doorstroom te bewerkstelligen is dat het ministerie van Justitie en Veiligheid ${ }^{6}$ deze zorg inkoopt bij zorgaanbieders (hoofdstuk 4), onder het mom van 'wie betaalt bepaalt'. Dit beleid was al ingezet sinds 2008, en vond vanaf 2011 plaats op basis van het Interimbesluit forensische zorg, en vindt in deze wet slechts zijn 'codificatie'? Al lezend kan men zich afvragen hoe nodig dat was, nu nadrukkelijk grotendeels beleidstaal tot wettekst is verheven.

Voor de reikwijdte van de wet is het vooraleerst van belang te weten hoe forensische zorg gedefinieerd is. De definitie uit artikel 1.1 lid $2 \mathrm{Wfz}$ is lang en voor slechte verstaanders van beleidsterminologie welhaast onnavolgbaar. ${ }^{8}$ Kort gezegd gaat het om de verlening van geestelijke gezondheidszorg op basis van een strafrechtelijke titel. In een eerdere versie van het wetsvoorstel stonden al deze titels nog opgesomd, maar op deze manier kan met die opsomming flexibeler worden omgegaan. ${ }^{9}$ Deze definitie richt zich dus vooral op het woord 'forensisch'. Forensische zorg is doorgaans gericht op de behandeling van stoornissen en beperkingen die aan delictgedrag ten grondslag liggen om zo recidiverisico terug te dringen. Voor definitie van het woord 'zorg' wordt verwezen naar de betekenis daarvan in de Wvggz en de Wet zorg en dwang (Wzd). Zorg kan qua inhoud bestaan uit bejegening,

4 Vergelijk voor dat dynamische karakter, afgezien van de hierna nog te bespreken indicatiestelling, bepalingen als art. 2.1 lid $2 \mathrm{Wfz}$, en art. 2.5 Wfz over adequate actie uiterlijk zes weken voor afloop van de strafrechtelijke titel, mocht ook daarna verdere zorg aangewezen zijn.

$5 \quad$ Kamerstukken II 2009/10, 32398, 3, onder 2.

6 Art. 1.1 lid $1 \mathrm{Wfz}$ hanteert nog de vorige, omgekeerde volgorde van Veiligheid en Justitie.

7 Dit besluit (Stb. 2010, 875) wordt door de Wfz vervangen.

8 Zoals gewijzigd door art. 14:4 onder A Wvggz, tweede nota van wijziging.

9 Er zijn nu 26 forensische zorgtitels, zie: www.forensischezorg.nl/introductie/keten-forensische-zorg/ forensische-zorgtitels; al weer een hele andere opsomming dan ooit in het oorspronkelijke wetsvoorstel. 
verzorging, verpleging, behandeling, begeleiding, bescherming, beveiliging en verplichte zorg. ${ }^{10}$

Wat forensische zorg is, wordt dus vooral begrensd door het 'forensische' in de definitie, het strafrechtelijk kader. Zo is (verplichte) geestelijke gezondheidszorg op basis van een machtiging uit de nieuwe civielrechtelijke wetten dus geen forensische zorg. Dat geldt opvallenderwijs ook voor de afgifte van een dergelijke zorgmachtiging door de strafrechter in artikel $2.3 \mathrm{Wfz}$, waarover later meer.

\section{Verwachte knelpunten: strafrechtelijke belangen versus doorstroom/zorg}

Onder de strafrechtelijke of forensische zorgtitels vallen modaliteiten uit alle fasen van het strafproces. Zowel tijdens de vervolging (te denken valt aan een sepot of strafbeschikking onder voorwaarden), als tijdens de berechting (sancties) en bij tenuitvoerlegging van sancties (zoals overplaatsingen) is forensische zorg mogelijk. Er is dus sprake van verschillende 'beslissers'. Zo heeft tijdens de vervolging de officier van justitie (OvJ) vaak beslissingsbevoegdheid, worden sancties doorgaans door de rechter opgelegd, en beslist de minister (en soms zelfs de Kroon, over voorwaardelijke gratie) tijdens de tenuitvoerlegging. ${ }^{11}$ Vervolgens is er een belangrijk onderscheid in de interne rechtspositie tussen gedwongen en 'vrijwillige' ofwel 'gedrongen' kaders, vaak het verschil tussen vrijheidsbenemende en vrijheidsbeperkende kaders. Deze laatste zijn als sancties vaak voorwaardelijke modaliteiten, maar ook overplaatsingen vanuit justitiële inrichtingen naar de ggz gelden doorgaans als zodanig. Daarmee vallen ze (tenzij uitgezonderd in de schakelbepaling van artikel 51 Wet Bopz) niet onder de huidige wetgeving voor gedwongen zorg, maar onder de Wet op de geneeskundige behandelingsovereenkomst (WGBO), die nauwelijks inbreuken op rechten en vrijheden ten behoeve van de veiligheid mogelijk maakt. Ook onder de toekomstige wetten blijven veel inbreuken voor die groep onmogelijk, ${ }^{12} \mathrm{al}$ wordt het soms wel mogelijk om in combinatie hiermee nog een machtiging tot verplichte zorg af te geven (zie par. 3). De Wfz zelf verandert niets aan de interne rechtspositie van justitiabelen.

Men kan twijfelen aan de meerwaarde van artikel 2.1 lid $1 \mathrm{Wfz}$ dat het doel van de forensische zorg omschrijft: 'Met inachtneming van het karakter van de vrijheidsbenemende straf of maatregel wordt de tenuitvoerlegging hiervan zo veel als mogelijk aangewend voor herstel van de forensische patiënt en vermindering van de kans op recidive, ten behoeve van de veiligheid van de samenleving.' Dit lijkt sterk op de - inhoudelijk net weer even andersluidende - bepalingen van gelijke strekking van artikel 2 lid $2 \mathrm{Pbw}$ en artikel 2 lid $1 \mathrm{Bvt}$, waarin de resocialisatiebeginselen worden genoemd. Het artikel geeft in ieder geval aan dat

10 Kamerstukken II 2015/16, 32399, 25, p. 223. In de Wvggz zijn alle vormen van verplichte zorg uitputtend opgesomd in art. 3:2. In de Wzd staan dezelfde vormen in art. 2:1 opgesomd onder de definitie 'onvrijwillige zorg', omdat de Wzd een afwijkende terminologie gebruikt. In de Rfz worden nog enkele andere belangrijke vormen van zorg aangewezen als forensische zorg. Dat zijn onder andere beschermd wonen en begeleiding, waaronder ambulante begeleiding en dagactiviteiten ('Wmo-zorg').

11 De verantwoordelijkheid van de minister van Justitie en Veiligheid voor de tenuitvoerlegging van strafrechtelijke beslissingen staat (nog) in art. 557 Sv en komt sterker terug in de Wet herziening tenuitvoerlegging strafrechtelijke beslissingen.

12 In de Wvggz is de schakelbepaling art. 9:1, daarin wordt onderscheid gemaakt tussen personen op een tbsof pij-titel (wat als verplichte zorg wordt beschouwd) en personen die met instemming in de instelling verblijven (enige inbreuken worden van toepassing verklaard). 
andere strafrechtelijke belangen, zoals vergelding of bescherming van de samenleving, bepaald nogal eens voorrang hebben ten opzichte van (forensische) zorg.

Dat blijkt ook bij de indicatiestelling, die juist bij uitstek uitdrukking zou moeten geven aan de persoonsgerichte benadering; de vaststelling van de aangewezen combinatie van behandeling en beveiliging. Dat maatwerk wordt soms doorkruist door de juridische titel. In dat geval wordt volgens artikel 5.1 lid $2 \mathrm{Wfz}$ de indicatiestelling aan de titel aangepast. ${ }^{13}$ Die volgorde blijkt ook uit artikel 5.1 lid $4 \mathrm{Wfz}$, dat bepaalt dat als bij behandeling van een strafzaak (in eerste aanleg of in hoger beroep) van de wenselijkheid van forensische zorg blijkt, de rechter daartoe zonder indicatiestelling kan beslissen. Daarnaast kan omwille van de beveiliging de Ovj op grond van artikel 5.2 lid $4 \mathrm{Wfz}$ gelasten dat in 'spoedeisende gevallen' forensische zorg wordt verleend voordat een indicatiestelling heeft plaatsgevonden c.q. voordat over een strafrechtelijke titel is beslist. Zo kan omwille van de veiligheid het systeem worden doorkruist. In dit geval betekent dat wellicht snellere doorstroom, maar overige veiligheidsmaatregelen in de wet zouden die doorstroom juist wel eens kunnen hinderen.

Op zich is de gedachte dat meer veiligheidsmaatregelen binnen de (forensische) ggz de doorstroom zouden moeten bevorderen niet onlogisch. Immers blijkt vaak de overgang tussen de zuilen van strafrecht en ggz een te grote sprong, vooral ook vanwege het cultuurverschil. Uit eerdere analyses blijken naast verschillen in de financieringssystematiek, vooral verschillen in de interne rechtspositie - de inperkingsmogelijkheden van rechten en vrijheden - en de regels rond gegevensuitwisseling. ${ }^{14}$ Hoewel de Wfz juist de financieringssystematiek aanpakt, blijven er ook daarin nog wel hobbels over; bijvoorbeeld de sprong van forensische zorg naar (verplichte) ggz-zorg. Ten aanzien van de uitwisseling van relevante gegevens staat in artikel 2.6 lid $6 \mathrm{Wfz}$ dat de zorgaanbieder informatie over behandeltrouw en een risico-inschatting verstrekt bij, bijvoorbeeld, de overgang naar de reclassering als verantwoordelijke partij. ${ }^{15}$ Echter, kennelijk twijfelt men of hiermee ten behoeve van de beveiliging het beroepsgeheim (voldoende) doorbroken kan worden; dit blijkt wel uit het feit dat hierover naar aanleiding van de recente casus Michael P. verdergaande regelgeving is toegezegd. ${ }^{16}$

13 De minister wijst blijkens art. 5.2. Wfz het tot indicatiestelling bevoegde orgaan aan dat een indicatiestelling afgeeft aan de rechter, de officier van justitie, de rechter-commissaris, de advocaat-generaal dan wel de minister. Indicatiestelling blijft gedaan worden door een onderdeel van het Nederlands Instituut voor Forensische Psychiatrie en Psychologie (NIFP). Als een vrijheidsbenemende titel voorhanden is, kan opname in een instelling voor indicatiestelling plaatsvinden: art. $6.9 \mathrm{Wfz}$.

14 Zie voor een analyse: J. Legemaate, M.C. Ploem, J. uit Beijerse, P.A.M. Mevis, M.J.F. van der Wolf, C.P.M. Akerboom, M. Schol, H. Winter \& N. Woestenburg, Thematischewetsevaluatie gedwongen zorg, Den Haag: ZonMW 2014, hoofdstuk 4: 'Gedwongen forensische zorg voor volwassenen'.

15 In art. $2.4 \mathrm{Wfz}$, lid 2 staat ook dat de minister (in plaats van het OM) de reclassering opdracht kan geven begeleiding te bieden en toezicht te houden. Dit is een lex specialis ten opzichte van de algemene regels in het Wetboek van Strafrecht. Het gaat om begeleiding/toezicht tijdens detentiefase of als gevolg van een voorwaardelijke gratieverlening.

16 Zie het verslag van de bijeenkomst van de Vaste Kamercommissie voor Justitie en Veiligheid op 26 juni 2019. 
Dan blijft over het verschil in interne rechtspositie als hobbel voor de overgang. De sprong van gedwongen naar vrijwillig kader is al besproken, maar ook de overgang van het regime van een justitiële beginselenwet naar dat van verplichte zorg in de ggz kan soms niet verantwoord gemaakt worden door gebrek aan inperkingsmogelijkheden. Hoewel de parlementaire discussie over de Wfz bewust is aangehouden om het wetsvoorstel tegelijk met de beide civielrechtelijke zorgwetten te behandelen, heeft dit niet geleid tot een complete harmonisatie van rechtsposities van gedwongen zorg. Met name het argument dat bepaalde inbreuken niet bij de cultuur van de ggz passen en dat 'de goeden niet onder de kwaden mogen lijden' heeft hierbij een rol gespeeld. Hoewel er in die wetten wel meer inbreuken op rechten en vrijheden mogelijk worden dan onder de Wet Bopz, zijn deze nog niet op het niveau van de justitiële beginselenwetten, zodat verschillen in beveiligingsmogelijkheden ook in de toekomst doorstroom kunnen blijven hinderen. Het is maar zeer de vraag of de nieuwe mogelijkheid van verplichting tot opname (art. 6.1 lid $3 \mathrm{Wfz}$ jo. art. 6.6. Bfz: zelfs op straffe van een bestuurlijke boete) dergelijke hindernissen in de praktijk zullen (kunnen) slechten.

Zo staan er wel meer maatregelen in de Wfz die, gezien de doelgroep wellicht te verwachten, vooral de schijn van controle en veiligheid (moeten) wekken. Zo moet de minister meldingen ontvangen van ongeoorloofde afwezigheid en andere incidenten (art. 6.10 Wfz). Waar de minister vroeger vooral Kamervragen over tbs-gestelden mocht verwachten, breidt dat zich nu uit naar de gehele forensische zorg.

\section{De strafrechtelijke zorgmachtiging van artikel $2.3 \mathrm{Wfz}$}

Het meest directe middel voor doorstroom, maar nog veel vragen

In de Wfz wordt wel een direct middel tot doorstroom gecreëerd dat het beleidsniveau overstijgt en echt als noviteit mag gelden: een zorgmachtiging in de zin van de Wvggz/ $\mathrm{Wzd},{ }^{17}$ maar dan opgelegd door de strafrechter.

Er bestond weliswaar al de mogelijkheid voor de strafrechter om een plaatsing in het psychiatrisch ziekenhuis op te leggen (art. 37 Sr), maar dan alleen tijdens de berechting in het geval dat iemand op basis van ontoerekeningsvatbaarheid ontslagen werd van alle rechtsvervolging (en voldeed aan het gevaarscriterium). Artikel $37 \mathrm{Sr}$ wordt door de Wfz geschrapt, omdat artikel 2.3 dat artikel 'absorbeert'. 'Vervangt' is hier als woord te eng, omdat de nieuwe mogelijkheid een veel ruimer toepassingsbereik heeft. De materiële criteria van artikel $37 \mathrm{Sr}$ vervallen dus voor de strafrechter, die daarmee gebonden is aan de criteria van de civielrechtelijke wetten en die dus ook moet kennen. ${ }^{18}$ Een belangrijke vraag is daarbij in hoeverre bij de forensische doelgroep kan worden beoordeeld dat het ernstig nadeel volledig voortkomt uit de stoornis. Ook procedureel verandert er veel, nu deze beslissing niet slechts tijdens de berechting kan worden genomen, maar op elk moment in het strafproces.

17 In het kader van de Wzd kan de strafrechter enkel opname machtigen. In het vervolg zullen we ons vooral richten op de Wvggz, omdat hier meer haken en ogen aan zitten.

18 Zie voor de beschrijving hiervan de overige bijdragen in dit nummer. 
Zo wordt het mogelijk om in verschillende fases van het strafproces de parallelle route voor het inzetten van civiele zorg te bewandelen; bijvoorbeeld bij een beslissing over voorlopige hechtenis aan het begin van het proces tot en met de beslissing over de beëindiging van de tbs-maatregel aan het eind. Waar deze laatste mogelijkheid echt een bestaand probleem oplost - een mooi aansluitende overgang van tbs naar ggz - zijn er veel andere mogelijkheden die juist allerlei problemen oproepen. In geval van de berechting loopt een civiele procedure naast de strafzaak. Naast het vonnis dient dus ook een afzonderlijke (civielrechtelijke) beschikking te worden afgegeven. Dit zou de strafrechter de mogelijkheid geven om een integrale afweging te maken tussen straf en zorg (of een combinatie daarvan). ${ }^{19}$ Dat is ook de reden waarom, in afwijking van de beslistermijn in reguliere Wvggz-zaken, ervoor gekozen is door de wetgever dat de beslissing in de strafzaak en de separate beslissing op het verzoekschrift tot afgifte van een zorgmachtiging gelijktijdig genomen (moeten) worden.

Procedureel zitten er nog wel wat haken en ogen aan, nu openbare behandeling van zowel straf- als civiele zaak het uitgangspunt is. ${ }^{20}$ Dat is een ongelijkheid met de civielrechtelijke zorgmachtigingsprocedure en het zal voor een kwetsbare betrokkene ook heftig kunnen zijn het over dergelijke zaken te hebben, mede ten overstaan van slachtoffers of nabestaanden en pers. Ook is bijvoorbeeld de vraag hoe de deskundigen in beide onderdelen van de zaak zich tot elkaar verhouden, zoals de pro Justitia-rapporteur die adviseert een zorgmachtiging te onderzoeken versus de psychiater die daarvoor geen medische verklaring wil afgeven. Ook ten aanzien van het recht te worden gehoord, en het recht op een gespecialiseerde advocaat bestaan vanwege deze samenloop van een straf- en civiele zitting vragen. Tegen beide 'onderdelen' bestaan ook verschillende rechtsmiddelen, zodat in een hogere instantie de beslissing over straf en zorg niet meer altijd integraal wordt afgewogen maar uiteen gaat lopen. ${ }^{21}$ Hoger beroep tegen een afgegeven zorgmachtiging behoort namelijk anders dan tegen de strafrechtelijke beslissing niet tot de mogelijkheden, enkel cassatie in het belang der wet. ${ }^{22}$

Ook de mogelijkheid dat de strafrechter op 'losse' vordering kan beslissen over een verzoekschrift tot afgifte van een zorgmachtiging van de OvJ - dus niet tijdens een beslissingsmoment in het strafproces - schept een nieuwe procedurele vraag. Wanneer gaat het Openbaar Ministerie (OM) hiervoor naar de strafrechter in plaats van de burgerlijke rechter (wat immers ook kan, bijvoorbeeld na sepot)? Uit artikel 2.3 lid $1 \mathrm{Wfz}$ blijkt dat de strafrechter bevoegd is kennis te nemen van een verzoekschrift tot afgifte van een zorgmachtiging wanneer sprake is van 'strafrechtelijke handhaving van de rechtsorde'. Noch bij wet, noch in de toelichting op de wet wordt dit criterium nader gedefinieerd. Enkel wordt opgemerkt dat er 'een link' met het strafrecht of de veiligheid van de samenleving dient te zijn. ${ }^{23}$ Het zal zich dus in de (rechts)praktijk moeten uitkristalliseren wanneer precies

21 Tenzij de advocaat-generaal (A-G) opnieuw een verzoek tot zorgmachtiging indient, dan wel wanneer het hof de A-G ambtshalve verzoekt een verzoek tot zorgmachtiging voor te bereiden.

22 Art. 6:1 lid 10 Wvggz. Ook is de zorgmachtiging uitvoerbaar bij voorraad, art. 6:4 lid 6 Wvggz.

23 Kamerstukken II 2015/16, 32399, 25, p. 224 (tweede nota van wijziging Wvggz). 
sprake is van strafrechtelijke handhaving van de rechtsorde en of dit criterium eng of ruim zal worden uitgelegd.

$\mathrm{Nu}$ ontoerekeningsvatbaarheid niet langer is vereist, ontstaat de mogelijkheid dat de zorgmachtiging ook naast een straf plaatsvindt. Het andere uiterste is dat de loskoppeling van de uitkomst in de strafzaak betekent dat ook bij vrijspraak een zorgmachtiging kan worden afgegeven. $\mathrm{Nu}$ in de regelgeving niets wordt geregeld over combinatie- dan wel samenloop(on)mogelijkheden of executievolgordes, moeten die vooralsnog worden afgeleid uit andere regels. Met name het feit dat de zorgmachtiging binnen twee weken nadat deze is afgegeven ten uitvoer moeten worden gelegd, zegt iets over de combinatie met bijvoorbeeld een gevangenisstraf. Daarbij speelt ook de complicerende factor dat de Wvggz anders dan de Wet Bopz niet enkel een opnamewet is, maar ook andere vormen van verplichte zorg kan inhouden zonder opname. Er openbaart zich zo een caleidoscoop aan nieuwe mogelijkheden. Zo lijkt de lengte van de gevangenisstraf (bijvoorbeeld niet langer dan het voorarrest) te bepalen welke executievolgorde naast een opname mogelijk is. ${ }^{24}$ En in geval van dwangmedicatie bijvoorbeeld is de vraag of dat wel naast gevangenisstraf kan, of dat dan de regeling rond dwangmedicatie uit de Pbw voorrang krijgt. Die bepaalt dat dit in minder acute situaties alleen kan in een Penitentiair Psychiatrisch Centrum (PPC), maar als men dan dwangmedicatie wil op een reguliere gevangenisafdeling, kan dit dan via (de minder hoge drempel van) de Wvggz? Zomaar wat vragen, waarop het antwoord bij inwerkingtreding onduidelijk is en de toekomstige praktijk het antwoord zal leren. Ook de combinatie met voorwaardelijke modaliteiten leent zich voor creatieve constructies, zoals de mogelijkheid om noodzakelijk geachte voorwaarden, zoals bijvoorbeeld dwangmedicatie of separatie waarmee men niet wil instemmen, via een zorgmachtiging te verplichten.

Verwachtingen over ruimere toepassing: plussen en minnen

Als beschreven heeft artikel 2.3 Wfz dus, zowel materieel als procedureel, een ruimer toepassingsbereik dan artikel $37 \mathrm{Sr}$. Opgeteld bij het doel van de Wfz is af te leiden dat een ruimere toepassing ook wordt beoogd. Daarbij is ook nog nagedacht over een belangrijk aspect dat de artikel 37-plaatsing vanuit het oogpunt van veiligheid minder aantrekkelijk maakte, namelijk de mogelijkheid dat de geneesheer-directeur voor het einde van de duur van de machtiging zelf een beslissing kon nemen over beëindiging van de opname. ${ }^{25} \mathrm{De}$ zorg over deze praktijk was dat hierbij de veiligheid nogal eens ondergeschikt werd gemaakt aan overwegingen rond (effectiviteit van) psychiatrische zorg. Artikel 8:18 lid 4 Wvggz bepaalt dat in het geval van opname voor tussentijdse beëindiging (of onderbreking) de minister van Justitie en Veiligheid om instemming moet worden gevraagd. Uit de wetsgeschiedenis wordt niet precies duidelijk hoe en waaraan de minister alsdan gaat toetsen. ${ }^{26}$ Het zou primair gaan om de vaststelling dat er geen grondslag meer bestaat om de vrijheid van de betrokkene te benemen of te beperken, ${ }^{27}$ maar waarbij de insteek gezien de

24 Overigens ligt het niet voor de hand een zorgmachtiging te verzoeken naast een lange gevangenisstraf. De combinatie van straf en zorgmachtiging wordt vooral verwacht bij een 'klein delict, grote zorgen'-situatie.

25 Zie M.J.F. van der Wolf, 'De beperkingen van de strafrechtelijke plaatsing in de GGZ (artikel 37 Sr)', Sancties 2017, p. 74-80.

26 Kamerstukken II 2015/16, 32399, 25, p. 183 (tweede nota van wijziging Wvggz).

27 Kamerstukken II 2011/12, 32398, 15. 
genoemde achtergrond toch wel zal zijn gelegen in de bescherming van de samenleving. Alleen wanneer de zorgmachtiging door de strafrechter is afgegeven naast een vrijspraak in de strafzaak geldt dit niet. ${ }^{28}$ Het is afwachten hoe de minister deze taak gaat vervullen. Het roept daarnaast ook de vraag op hoe het zit met de rechtsgelijkheid tussen een betrokkene die een zorgmachtiging opgelegd krijgt van de civiele rechter versus degene die de zorgmachtiging krijgt van de strafrechter. En hoe dit zich verhoudt tot het uitgangspunt van de Wfz, namelijk dat het voor de zorg geen verschil maakt of iemand nu verdacht wordt van het plegen van een strafbaar feit, en daarvoor wel of niet voor veroordeeld wordt, of wanneer daar geen sprake van is.

Een andere mogelijkheid om de veiligheid te vergroten is dat zowel bij de strafrechtelijke als civielrechtelijke zorgmachtiging de rechter kan bepalen dat de opname ten uitvoer wordt gelegd in een Forensisch Psychiatrisch Centrum (FPC) oftewel een tbs-kliniek. ${ }^{29}$ Dat beantwoordt niet alleen de roep om makkelijkere toegang tot een hoger beveiligingsniveau vanuit de ggz, maar komt ook tegemoet aan de wens vanuit tbs-klinieken om zo veel mogelijk dezelfde rechtspositie te kunnen hanteren voor tbs-gestelden versus civielrechtelijk geplaatsten. Deze wens werd sterker toen door afname van de tbs-populatie meer bedden aan Bopz'ers werden besteed. Daarom is geregeld dat de rechter hiermee meteen bepaalt dat in een dergelijk geval de interne rechtspositie van de Bvt geldt. Dat is dus een breuk met het systeem van de Wvggz waarin de interne rechtspositie op maat (en dus per individu) wordt meegeregeld in de zorgmachtiging. Dat lijkt aantrekkelijk voor de strafrechter, nu die niet anders gewend is dan dat er niet hoeft te worden nagedacht over de interne rechtspositie. Maar nu onder invloed van de casus Michael P. de tbs-populatie weer groeiende is, is het maar zeer de vraag in hoeverre er plaats is in FPC's voor personen met een zorgmachtiging op deze dure bedden. De artikel 37-doelgroep kwam grotendeels terecht in Forensisch Psychiatrische Klinieken (FPK's) en op Forensisch Psychiatrische Afdelingen (FPA's), die een lager beveiligingsniveau kennen dan een FPC. Het is maar zeer de vraag of mensen met een strafrechtelijke zorgmachtiging daar gemakkelijk terecht zullen kunnen komen, nu het merendeel van de bedden in dergelijke inrichtingen immers ingekocht is voor forensische zorg. In het slechtste geval moet men afzakken naar het beveiligingsniveau in de reguliere ggz. Men zal daarvoor al snel als te gevaarlijk beoordeeld worden en dan ligt voor deze doelgroep het ingrijpendere alternatief van tbs op de loer.

Waar de duur van de artikel 37 Sr-plaatsing maximaal twaalf maanden was, is die van de zorgmachtiging in beginsel zes maanden. ${ }^{30}$ Dat zal de zorgmachtiging minder aantrekkelijk maken vanuit het oogpunt van beveiliging, nu er al vaak kritiek klonk op de duur van een jaar als te kort om het recidiverisico voldoende te reduceren. Daarnaast krijgt het toewijzen van een verzoek tot afgifte van een zorgmachtiging, in tegenstelling tot het opleg-

28 Art. 8:18 lid 4 Wvggz. In het oorspronkelijke wetsvoorstel gold dat ook nog voor ontslag van alle rechtsvervolging (OVAR), maar dat was vreemd nu dit de voornaamste kritiek was op de art. 37 Sr-plaatsing waarvoor via ontoerekeningsvatbaarheid OVAR was vereist.

29 Art. 6:4 lid 3 (tijdelijke plaatsing) en lid 4 (definitieve plaatsing) Wvggz.

30 Echter, bij een aansluitende zorgmachtiging is de maximale duur twaalf maanden en zelfs twee jaren wanneer het een persoon betreft aan wie gedurende ten minste de afgelopen vijf jaren verplichte zorg is verleend (art. 6:5 Wvggz). Dit zou de strafrechtelijke zorgmachtiging voor personen die strafbare feiten plegen in gesloten inrichtingen juist weer aantrekkelijker maken. 
gen van de maatregel ex artikel 37 Sr, geen vermelding op de justitiële documentatie van betrokkene, daar het een civiele maatregel betreft. Ook zal de strafrechter, wanneer het om de Wvggz gaat, moeten wennen aan het systeem dat andere verplichte zorg als alternatief of naast opname cumulatief als interne rechtspositie kan/moet worden meegeregeld.

Ook het procedurele vereiste van advisering verandert ten opzichte van artikel 37 Sr. Daarvoor was een multidisciplinair advies aan de rechter vereist. Voor de zorgmachtiging is dat een medische verklaring. Overigens is het niet de rechter, maar de geneesheer-directeur die door de verzoekende OvJ is aangewezen, die bepaalt wie de onafhankelijke psychiater is die de medische verklaring opstelt en wie de zorgverantwoordelijke is die het zorgplan en de zorgkaart opstelt. Door deze procedure heeft de geneesheer-directeur die de strafrechtelijke klant moet gaan ontvangen wel enigszins sturing over de uitkomst van de daarvoor vereiste formaliteiten. $\mathrm{Nu}$ hoort men vanuit het strafrecht wel vaker gemor dat de ggz haar taak ten aanzien van de maatschappelijke veiligheid soms te gemakkelijk verwaarloost door een recidivegevaarlijke patiënt te ontslaan, op deze manier krijgt men invloed op de mogelijkheid om de klant überhaupt niet binnen te krijgen. Zo direct is dit instrument van doorstroom bij nader inzien wellicht toch niet voor de rechter. Overigens is de medische verklaring, net als de pro Justitia-rapportage in de strafzaak, te beschouwen als een deskundigenbericht, waartoe de rechter zich zal moeten verhouden, maar waaraan hij niet gebonden is. ${ }^{31}$ Uiteindelijk moet de rechter ook (ex art. 6:4 lid 2 Wvggz) ambtshalve beslissen over welke vormen van verplichte zorg nodig zijn en per vorm voor welke maximale duur. Een niet direct zuiver juridische beslissing, laat staan een strafrechtelijke, die voor de rechter ver van zijn bed zo niet buiten de competentiesfeer ligt. ${ }^{32}$ Vanuit het oogpunt van rechtsbescherming ondermijnt dat uiteraard de waarde van de rechterlijke toets die beoogd is.

Kan dit allemaal wel van de strafrechter verlangd worden? Is de strafrechter voor een dergelijk verzoek wel de juiste ingang? Er dringen zich vergelijkbare procedures op, die reeds eerder al op het bordje van de strafrechter zijn gelegd. De strafrechter die wordt geconfronteerd met de civiele vordering van de benadeelde partij, een ontnemingsvordering moet behandelen of zich uit moet laten over beslagen. Ook hier wordt van de strafrechter verwacht buiten zijn eigenlijke expertise te beslissen. Uiteindelijk constateren wij dat voor al deze 'aanvullende werkzaamheden'toch weeroplossingen zijn of werden gezocht buiten het onderzoek ter zitting in de richting van een beklagkamer, de separate behandeling van grote, ingewikkelde ontnemingsvorderingen door een gespecialiseerde kamer en de verwijzing naar de civiele rechter indien een vordering van de benadeelde partij te ingewikkeld is. De toekomst van de strafrechtelijke zorgmachtiging lijkt ons, dit alles overziende, allesbehalve zeker.

31 W. Dijkers, 'Een witte jas onder de toga', NJB 2018/1139.

32 De vraag kan worden opgeworpen in hoeverre juist de strafrechter niet geneigd zal zijn tot het tekenen van een 'blanco cheque', waarin alle (of veel) vormen van verplichte zorg voor de maximale duur worden gemachtigd om de zorgverantwoordelijken vervolgens tijdens de zorg te laten uitmaken wat echt nodig is. 


\section{De doorbreking van het medisch beroepsgeheim bij weigerende observandi}

Een stevig middel voor een eigenstandig doel

In artikel 7.1 onder F Wfz - het omvangrijke hoofdstuk 7 is getiteld 'Wijziging van andere wetten' - wordt artikel 37a Sr, de regeling van oplegging van de tbs-maatregel, zo gewijzigd dat in lid 5 tot en met 9 een procedure staat betreffende de doorbreking van het medisch beroepsgeheim bij weigerende observandi. Deze wijziging vloeit geenszins rechtstreeks voort uit de oorspronkelijke doelstelling van de Wfz (doorstroom bevorderen). De behoefte aan de regeling is tijdens de totstandkomingsgeschiedenis ontstaan naar aanleiding van een burgerinitiatief over de - vermeende - onmogelijkheid voor de strafrechter om tbs op te leggen ingeval de verdachte weigert aan gedragskundige observatie mee te werken, waarmee de bescherming van de samenleving in het geding zou zijn. ${ }^{33}$ Het gaat dan vooral om het oplossen van het materieelrechtelijke probleem bij de verdachte een stoornis vast te stellen ten tijde van het delict, vereist voor tbs-oplegging. Achteraf beschouwd was het niet handig om deze regeling in te voegen in de Wfz, terwijl deze daar inhoudelijk niet mee samenhangt, nu de behandeling van die wet is uitgesteld om met de Wvggz en Wzd samen behandeld te worden. Al was een lange discussie vanwege de ingrijpendheid van de regeling ook weer geen overbodige 'luxe'.

De gedachte achter de regeling is op zichzelf niet onbegrijpelijk. Als de verdachte niet meewerkt aan gedragskundige rapportage en die weigering adequate advisering en daarmee oplegging van tbs kan beletten, dan kan het aangewezen zijn andere relevante gegevens over de verdachte aan de gedragsdeskundigen ter beschikking te stellen, ook zonder toestemming van de verdachte, opdat mede op basis daarvan beter kan worden geadviseerd en beslist. Artikel 37a lid $5 \mathrm{Sr}$ (nieuw) spreekt ter zake van 'persoonsgegevens betreffende een mogelijke gebrekkige ontwikkeling of ziekelijke stoornis van de geestvermogens van betrokkene, ten aanzien waarvan de verdachte niet bereid is om medewerking te verlenen aan de verstrekking'. Daarbij kan men bijvoorbeeld denken aan gegevens betreffende '(civiele) psychiatrische ziekenhuisopnames in het verleden'. ${ }^{34}$ Omdat het gebruiken van deze gegevens onvermijdelijk gepaard gaat met een inbreuk op het medisch beroepsgeheim dat op die gegevens rust, wordt een uitvoerige procedure opgetuigd om die inbreuk proportioneel te houden. Zo is de belangrijkste waarborg dat een multidisciplinaire commissie op verzoek van de OvJ onderzoek doet en advies uitbrengt over de aanwezigheid en de bruikbaarheid van dergelijke gegevens. De OvJ ziet die gegevens zelf (dus) niet. De arts of gedragsdeskundige die in dat onderzoek om betreffende persoonsgegevens wordt verzocht is verplicht deze binnen vijf werkdagen elektronisch te verstrekken. ${ }^{35}$ Het gaat daarbij altijd om het gehele dossier; een selectie van de betreffende behandelaar is uit-

33 De voorziening is bij de tweede nota van wijziging (Kamerstukken II 2012/13, 32398, 19) aan de Wfz toegevoegd en vervangt daarmee het in de eerste nota van wijziging (Kamerstukken II 2012/13, 32398, 10) opgenomen voorstel. Bij amendement (nr. 23) is de toetsende rechter gewijzigd van rechter-commissaris in de Penitentiaire Kamer van Hof Arnhem-Leeuwarden.

34 Kamerstukken II 2011/12, 32398, 10, p. 22 en Kamerstukken II 2012/13, 32398, 19, p. 14. Rapporten en adviezen die in eerdere strafzaken over de verdachte zijn uitgebracht, kunnen reeds aan het dossier in nieuwe zaken worden toegevoegd. Daarop is de regeling dus niet van toepassing, Kamerstukken II 2012/13, 32398, 19, p. 22. 
drukkelijk niet aangewezen; ${ }^{36}$ alleen de commissie heeft een 'zeeffunctie' ten aanzien van de gegevens. ${ }^{37}$ Door meer partijen is erop gewezen dat dit dus weinig proportioneel aandoet en dat er ook informatie over derden in zou kunnen staan. Ook kan men zich afvragen in hoeverre het feit dat de selectie niet gecontroleerd wordt en ook niet door de verdediging betwist kan worden strookt met het recht op een eerlijk proces. Op basis van de gegevens adviseert de commissie de OvJ (binnen dertig dagen).

Andere waarborgen zijn de beperking tot verdenkingen van misdrijven gericht tegen of gevaar veroorzakend voor de onaantastbaarheid van het lichaam, ${ }^{38}$ en het 'ultimum remedium'-karakter van de regeling. Die is zo uitgewerkt dat de verdachte in ieder geval op grond van artikel 509g Sv ter observatie opgenomen is (geweest), bijvoorbeeld in het PBC. De resultaten van die observatie moeten dus eerst worden afgewacht en de regeling is dus niet mogelijk ingeval slechts ambulant is geobserveerd. ${ }^{39}$ Het voert dus in de uitwerking niet zover dat er eerst ook verlenging van de termijn in het PBC moet zijn. ${ }^{40}$ Een belangrijke waarborg is die van de machtiging van het gebruik van de gegevens door een rechter. ${ }^{41}$ Vanwege de bijzondere aard van de gegevens is ter zake in de - uiteindelijke regeling en op voorspraak van de Raad voor de rechtspraak de Penitentiaire Kamer van Hof Arnhem-Leeuwarden bevoegd gemaakt, waarin naast drie Raadsheren ook twee gedragsdeskundige Raden zitting hebben. Deze Kamer moet een machtiging verlenen tot het verstrekken van de gegevens aan de gedragsdeskundige, welke machtiging uitsluitend op vordering van het OM kan worden verleend. ${ }^{42}$ Aan deze Kamer wordt het advies van de commissie verstrekt, maar (ook) de Kamer ziet de gegevens zelf niet. ${ }^{43}$ De Kamer kan wel

36 Aldus uitdrukkelijk de toelichting bij het concept-Besluit adviescommissie gegevensverstrekking, p. 11 en, naar aanleiding van de sterke kritiek op dit onderdeel in de adviezen over het concept-besluit, p. 17-18.

37 Zie de toelichting bij het concept-Besluit adviescommissie gegevensverstrekking, p. 9 en p. 31 .

38 Er staat 'als bedoeld in artikel 38 Sr'; waarschijnlijk is bedoeld te verwijzen naar art. 38e Sr.

39 Art. 1.1.i onder a concept-Besluit adviescommissie. Zie de toelichting bij het concept-Besluit adviescommissie gegevensverstrekking, p. 11 en p. 24.

40 Op zich al relatief nieuwe regeling dat nogmaals zeven weken mogelijk is; art. 198 lid 2 Sv.

41 In die verstrekking ligt immers de doorbreking van het medisch beroepsgeheim en dan is - ook zonder EVRM-noodzaak - een oordeel van de rechter aangewezen. De tweede nota van wijziging bevat op p. 17-22 een uitvoerig betoog waarom het voorstel niet strijdt met regelingen ter bescherming van de persoonlijke levenssfeer op nationaal (Grondwet, Wbp) of Europees (EVRM) niveau. Het College bescherming persoonsgegevens (thans Autoriteit Persoonsgegevens) is daarvan blijkens zijn advies niet onder de indruk en oordeelt dat de noodzaak van het voorstel op dit punt onvoldoende is onderbouwd.

42 Ook als de commissie negatief adviseert, kan de OvJ de vordering doen. In de wetsgeschiedenis (Kamerstukken II 2012/13, 32398, 19, p. 16) worden daartoe 'zwaarwegende argumenten' verlangd. De vraag rijst waaraan de OvJ die zou moeten of kunnen ontlenen nu hij geen kennis kan nemen van de inhoud van de gegevens. Als ook het hof de machtiging verleent, impliceert zulks volgens de minister dat alle beschikbare gegevens naar de rapporteurs gaan, nu de commissie haar zeeffunctie ten aanzien van de gegevens niet heeft kunnen vervullen c.q. zij geen bruikbare gegevens heeft gevonden. Zie over dit punt ook Kamerstukken I 2012/13, 32398, F, p. 28-29 en de toelichting op het concept-Besluit adviescommissie gegevensverstrekking, p. 18.

43 'De rechterlijke machtiging bepaalt mitsdien of de gegevens aan de rapporteur verstrekt worden en het advies van de commissie als hoofdregel welke gegevens worden verstrekt', aldus de toelichting bij het concept-Besluit adviescommissie gegevensverstrekking, p. 31. 
de voorzitter van de commissie horen en nadere vragen stellen ${ }^{44}$ en zij moet, alvorens te beslissen, de verdachte horen. Alles afwegende - waaronder de correctheid van de gevolgde procedure, de proportionaliteit van de inbreuk, eventuele alternatieve wegen naar informatie en de bruikbaarheid van de gegevens bij een beslissing over tbs-oplegging - zal de Kamer over de machtiging beslissen. Tegen de beslissing van de Penitentiaire Kamer staat blijkens artikel 37a lid 7 Sr (nieuw) voor het OM 'of' (bedoeld zal zijn: 'en') de verdachte beroep in cassatie open. Doet de OvJ geen vordering of is de weigering een machtiging te verlenen onherroepelijk, dan worden de gegevens vernietigd.

\section{Verwachte knelpunten en betekenis van de regeling}

De regeling is niet zonder stevige weerstand tot stand gekomen. ${ }^{45}$ Daarmee zijn kleine, op zichzelf waardevolle, aanpassingen in de procedure bewerkstelligd, zoals het expliciet opnemen in het advies van gegevens waaruit blijkt dat bij de weigerende observandus géén sprake was van een gebrekkige ontwikkeling of ziekelijke stoornis van de geestvermogens. ${ }^{46}$ Maar het aanreiken van geheel alternatieve regelingen om doorbreking van het beroepsgeheim te voorkomen is niet gelukt. ${ }^{47}$ Daarmee staat de grondkritiek nog overeind, dat de regeling gevaar voor zorgmijding in het leven roept. Robbert-Jan Verkes, de voorzitter van de multidisciplinaire commissie, reageerde daarop in een interview. Het lijkt hem niet waarschijnlijk dat veel mensen psychische zorg zullen mijden uit angst dat deze informatie in de toekomst ooit tegen je gebruikt gaat worden omdat je verdacht wordt van een ernstig strafbaar feit. De enige categorie patiënten die hij daartoe in staat acht zijn planmatige kindermisbruikers; personen die de optie willen openhouden ooit tot misbruik over te gaan en om die reden thans geen openheid geven aan artsen of gedragskundigen ondanks lijdensdruk vanwege hun seksuele voorkeur. ${ }^{48}$ Hierbij wordt steeds aan het verleden gedacht, maar deze zorg zou wel betrekking kunnen hebben op de strikte scheiding van rapportage en zorg in het PBC. Als de zorgpsychiater gevraagd kan gaan worden door de rapporterend gedragskundigen of deze over klachten heeft gesproken, dan levert dat in de observatiekliniek een spannende situatie op.

44 In het advies van de commissie kan de voorzitter de wenselijkheid te worden gehoord tot uitdrukking brengen: vgl. art. 2.9 lid 2 van het concept-Besluit adviescommissie gegevensverstrekking. Voor deze "nadere uiteenzetting over het advies en de daaraan ten grondslag liggende gegevens' blijft het uitgangspunt dat de rechter geen kennis krijgt van de gegevens. Dat moet meebrengen dat de commissievoorzitter hier de grenzen moet bewaken en zich desnoods van het geven van te vergaande vragen naar de inhoud van de gegevens moet verschonen.

45 Van de voor advies geraadpleegde instanties reageerden de Raad van State, het College bescherming persoonsgegevens (thans Autoriteit Persoonsgegevens), de Nederlandse Orde van Advocaten, de KNMG, de Raad voor de rechtspraak, de Nederlandse Vereniging voor Psychiatrie en het College van P-G's in meer of minder sterke bewoordingen allemaal negatief.

46 Op verzoek van de Raad voor de rechtspraak en van de NOvA opgenomen in art. 2.9 lid 1 tweede volzin van het besluit.

47 Zoals de Autoriteit Persoonsgegevens probeerde, zie P.A.M. Mevis, S. Struijk \& M.J.F. van der Wolf, Juridische haalbaarheid van voorgestelde oplossingen voor de weigeraarsproblematiek omtrent tbs-oplegging, Den Haag: Boom juridisch 2018.

48 Zie www.medischcontact.nl/nieuws/laatste-nieuws/artikel/doorbreek-beroepsgeheim-om-tbs-beter-teonderbouwen.htm. 
De regeling levert mogelijk nog andere ongewenste situaties op. De WGBO voorziet namelijk niet alleen in het beroepsgeheim, maar ook in de plicht tot het op verzoek vernietigen van gegevens. Zal daarvan niet vaker gebruik worden gemaakt, zodat toepassing van de doorbrekingsregeling in zoverre een lege dop zal blijven? De minister wijst er in de toelichting van het concept-besluit allereerst opdat de behandelaar de patiënt niet over dit recht hoeft te informeren, maar de vraag rijst natuurlijk of behandelaars dat in de toekomst, gegeven de gevoelde weerstand, niet juist gaan doen. ${ }^{49}$ In geval van samenloop beveelt de minister aan de gegevens binnen de vijf dagen aan de commissie te verstrekken om de gegevens daarna binnen de WGBO-termijn van drie maanden te vernietigen. Mogelijk ontstaat er een soort race wie het eerst bij de gegevens is. Opmerkelijk is dat de minister het kennelijk ook denkbaar acht dat aan een verzoek tot vernietiging geen gehoor wordt gegeven op de grond dat iemand anders dan de patiënt een aanmerkelijk belang heeft bij het bewaren van gegevens. De minister noemt als zodanige anderen '(toekomstige) slachtoffers en nabestaanden'. ${ }^{50}$ Aangezien sprake moet zijn van een concreet en actueel belang, gaat de interpretatie dat gegevens bewaard kunnen blijven ten behoeve van de berechting van mogelijk in de toekomst te plegen strafbare feiten, aanzienlijk te ver. ${ }^{51}$ Een ander probleem is de duur van het gehele proces, zeker nu het ultimum-remediumkarakter eist dat eerst observatie heeft plaatsgevonden. Als de behoefte aan meer informatie pas op het onderzoek ter terechtzitting blijkt, zal er altijd ook een proceseconomische afweging plaatsvinden, juist ook ten opzichte van de verwachte meerwaarde van de gegevens.

De meerwaarde van de regeling is overigens langs twee lijnen te betwijfelen. Ten eerste is de vraag in hoeverre er uit de (oude) gegevens relevante inhoud tevoorschijn komt. Hierbij speelt een rol dat behandelaars weliswaar verplicht zijn om de informatie te verstrekken, maar die verplichting is vrijblijvend nu daar geen sancties op staan. Het gaat bijvoorbeeld niet om een bevel in de zin van artikel $184 \mathrm{Sr}$, zodat de verstrekking niet met (dreiging van) strafvervolging ter zake kan worden afgedwongen. Ook is er geen onderzoek mogelijk naar de waarachtigheid of volledigheid van de gegevensverstrekking. Een ander ingewikkeld punt, dat nog eens versterkt is doordat de Penitentiaire Kamer in de procedure is ingevoegd, is het feit dat de gegevens uiteindelijk bij de rapporterende gedragsdeskundigen in de huidige strafzaak terechtkomen. Het is maar zeer de vraag of zij blij zijn met (oude) gegevens waarvan twee hoge instanties op gedragskundig gebied gezegd hebben dat ze bruikbaar zijn. Wat doet dat met de eigen oordeelsvorming, of wat doet men als die gegevens niet overeenkomen met eigen bevindingen, ook in het licht van de tuchtrechtspraak? Verkes vindt dat het initiatief ook bij deze rapporteur moet liggen, dat die heel precies moet formuleren naar bepaalde informatie op zoek te zijn, om zodoende de proportionali-

49 Toelichting, p. 14. Betekenisvoller is de vaststelling van de minister dat de bestaande bewaarplicht van Bopzgegevens voor een termijn van vijf jaren in de Wvggz tot vijftien jaren wordt verlengd.

50 Toelichting, p. 14-15.

51 De bedoeling te monitoren of de regeling van art. 37a lid 5-9 Sr (nieuw) zal leiden tot een toename van verzoeken tot vernietiging van het dossier. Begrijpen wij de toelichting op dit onderdeel (p. 21) goed, dan overweegt de minister om al eerder met regelgeving te komen ter (ook alweer) 'verduidelijking' van de positie van de behandelaar die geen gevolg geeft aan een verzoek van de patiënt tot vernietiging van het dossier. 
teit van de inbreuk door de commissie te bewaken. ${ }^{52}$ Maar de vraag is hoe het OM, als officiële verzoeker, hiermee om zal gaan.

Ten tweede kan men vragen stellen bij de meerwaarde van de regeling, nu vaker is aangetoond dat de veronderstelling dat tbs aan weigeraars niet kan worden opgelegd niet klopt. Sinds de introductie van deze regeling in de tweede nota van wijziging van de Wfz is op allerlei manieren gebleken dat de rechter, ook onder de bestaande regelgeving in voorkomende gevallen, zeer wel in staat is om - ondanks weigering - tot het opleggen van tbs te (kunnen) beslissen. ${ }^{53}$ Hierbij speelt vooral de 'goedkeuring' van het EHRM dat de rechter in zo'n geval zelf de stoornis kan vaststellen een belangrijke rol. ${ }^{54}$ Sterker, men kan zich afvragen of het ultimum-remediumkarakter van de regeling niet vraagt of eerst moet worden afgewacht of de rechter in casu niet zelf al een stoornis kan vaststellen. Voor de gevoelde c.q. veronderstelde problematiek zijn bovendien inmiddels op onderdelen veranderingen en verbeteringen van bestaande regelingen gerealiseerd ${ }^{55}$ of aanstaande. ${ }^{56} \mathrm{Bij}$ eenieder die in dat kader de 'brede verkenning' van de aanpak van weigerende observandi met alle mogelijke middelen en wegen van de minister voor rechtsbescherming van 8 oktober 2018 leest, ${ }^{57}$ moet de vraag opkomen of aan de procedure van artikel 37a lid 5-9 Sr (nieuw) eigenlijk nog wel behoefte bestaat. De noodzaak van de voorgestelde regeling is nooit meer in het licht van die nieuwere ontwikkelingen bezien. Zeker tegen de achtergrond van de gevoelde weerstand tegen de regeling, had dat wel voor de hand gelegen.

\section{Tot besluit}

Het moge duidelijk zijn: een goed overzicht van de Wfz is niet gemakkelijk te verwerven en op onderdelen is stevige kritiek mogelijk over noodzaak, werkzaamheid en uitwerking van de wet. De doelen van doorstroom en maatwerk zullen met de voorgestelde middelen vaak hinder ondervinden van strafrechtelijke belangen, waaronder beveiliging. Het ruimere toepassingsbereik van de zorgmachtiging door de strafrechter is na optelling van alle plussen en minnen in de regeling nog geen zekerheid. En de onhandig ingepaste regeling van doorbreking van het beroepsgeheim bij weigerende observandi moet ook nog heel wat knelpunten omzeilen om haar verwachtingen waar te maken. De beschrijving van

52 Zie www.medischcontact.nl/nieuws/laatste-nieuws/artikel/doorbreek-beroepsgeheim-om-tbs-beter-teonderbouwen.htm.

53 Vgl. o.a. P.A.M. Mevis \& M.J.F. van der Wolf, 'Beschouwingen over weigeren en beveiligen n.a.v. de zaak Michael P.', DD 2018/27, p. 321-366 en M.J.F. van der Wolf, N. Gielesen \& F.J. Kaat, 'Wat wil de rechter met de weigeraar en waarom? Een analyse van recente jurisprudentie', Sancties 2018, p. 235-247.

54 De zaak Constancia $v$ The Netherlands (EHRM 3 maart 2015, nr. 73560/12).

55 Dat betreft in het bijzonder de mogelijkheid de observatietermijn ter verlengen; zie art. 198 lid 2 en 3 Sv, uit de Wet procedurele verbeteringen rechtspraktijk; Wet van 31 januari 2018; Stb. 2018, 30.

56 De consultatieversie van de Invoeringswet tenuitvoerlegging strafrechtelijke beslissingen beoogt de criteria voor het opleggen van tbs in art. 37a Sr te 'verduidelijken', zonder dat een materiële wijziging is beoogd. Voorgesteld wordt te benaderukken dat het stoorniscriterium een juridisch en geen gedragskundig criterium is en voorts dat het bij het opleggen van de tbs toch vooral ook moet gaan om de veiligheid van de samenleving (tbs als beveiligingsmaatregel). 
deze regelingen op het geduldige papier zegt in feite nog weinig over de werking en betekenis van de Wfz in de praktijk. Wij wachten in spanning af. 